\title{
腎細胞癌の腫瘍径が有する臨床的意義に関する検討
}

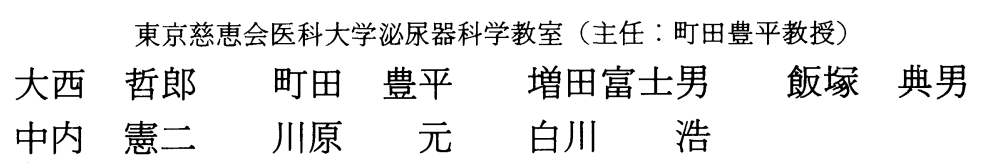

\section{STUDY ON CLINICAL CHARACTERISTICS IN RELATION TO SIZE OF RENAL CELL CARCINOMA}

\author{
Tetsuro Ohnishi, Toyohei Machida, Fujio Masuda, Norio Iizuka, Kenji Nakauchi, \\ Motoshi Kawahara and Hiroshi Shirakawa \\ Department of Urology, Jikei University School of Medicine
}

(Director: Prof. T. Machida)

Four hundred and thirty-one patients with renal cell carcinoma treated at Jikei University and its related institutions from 1957 to 1988 were studied as to tumour size in relation to clinical characteritics (age, sex ratio, affected side, symptoms), prognostic factor (fever, weight loss, anaemia, elevation of erythrocyte sedimentation rate), pathological staging, pathological grading, and survival. The treated patients were divided into 4 groups on the basis of tumour size (group A; under $3.0 \mathrm{~cm}$, group B; 3.1 to $5.9 \mathrm{~cm}$, group C; 6.0 to $9.9 \mathrm{~cm}$, group D; over $10 \mathrm{~cm}$ in diameter). At the time of operation, there were 22 cases (5.1\%) in group A, 121 cases (28.1\%) in group B, 209 cases $(48.5 \%$ ) in group C, and 79 cases (18.3\%) in group D.

In studying the clinical factors of age, sex ratio, and affected side, no relationship with size was detected. As for the symptoms, the larger the tumour, the more frequent the symptoms of urinary tract (haematuria, pain, and palpable mass). This tendency was especially marked in the cases of group D (over $10.0 \mathrm{~cm}$ in diameter). In addition, no relationships were observed between the rate of haematuria and the symptoms of extraurinary tract in each group.

As for the prognostic factors (fever, weight loss, anaemia and the elevation of erythrocyte sedimentation rate), there was an obvious tendency for a positive reaction of these factors in the cases of groups $\mathrm{C}$ and $\mathrm{D}$ (over $6.0 \mathrm{~cm}$ in diameter).

As for the distribution of stage and grade in each group, a higher stage and grade were observed with large sized tumours. Especially in stage IV B, cases of larger tumour size and higher grade predominated.

Survival declined with increasing size of tumour, but no significant differences were observed between groups $A$ and $B$, or groups $C$ and $D$. When analysing survival in relation to stage and grade in group A, certain tumour characteristics were found to be associated with a poor prognosis, e.g., high grade cases. Thus, even with smaller sized tumours (under $3.0 \mathrm{~cm}$ in diameter) attention must be paid to histological grade, and if the grade of tumour is high, postoperative powerful adjuvant therapy is needed to improve the prognosis for such cases.

Key words: renal cell carcinoma, tumour size, clinical characteristics

\footnotetext{
要旨：過去 32 年間に慈恵医大泌尿器科及び関連病院で治療した腎細胞癌 482 症例の内, 腎摘除術が施行さ れた 431 症例について, 腫瘍の長径から 4 群 (A 群 : $3.0 \mathrm{~cm}$ 以下；22例， B 群：3.1 5.9cm；121例, C 群：6.0 9.9cm; 209 例, $\mathrm{D}$ 群 : $10 \mathrm{~cm}$ 以上 $; 79$ 例 $)$ に分類し，各群別に臨床的特徵や，予後との関連に 関して比較検討した。

1）罹患年齢，性差，患側は，各群間に差は認められなかった。

2）初発症状からみると, 腫瘍径の増大に伴って, 尿路症状の頻度が高くなり, 特に $10 \mathrm{~cm}$ を越える群
} 
で腫瘤を触知する傾向が強かった，また，血尿の頻度及び，尿路外症状の頻度は各群間に差はほとんど 認められなかった。

3）発熱, 体重減少, 貧血, 赤沈の亢進の頻度は, 腫瘍径が $6.0 \mathrm{~cm}$ を越觉る群から多く認められる傾向 にあった。

4）腫瘍径の増大に伴って stage 及び grade が高くなる傾向が認められた.

5）各群別生存率を比較すると, A 群と B 群間の生存率に有意差はなく, C 群と D 群間の生存率も有 意差が認められなかったが，その他の群間の生存率に有意差が認められた。

6）各群別に, stage 及び grade 別生存率を分析した結果, 特に腫瘍径の小さいA 群に関しては stage より grade が予後を左右する因子と考光られた。

キーワード：腎細胞癌, 腫瘍径, 臨床的検討

\section{緒言}

腎細胞癌の最近の臨床的傾向として, 様々な画像診 断の発展と普及にともなって, 他科疾患検索中に, 偶 然腎細胞癌が発見される症例が比較的多く, しかも， これら症例は一般に腫瘍径が小さいといら指摘があ る1). しかもこれら症例はその他の症例に比較して, 予 後も良好であるとされている(1) .

今回, 教室の 431 症例を中心に, 腫瘍径からみた臨床 的特徵や, 予後との関連について検討を試みたので報 告する.

\section{対象症例と検討項目}

1957年 1 月より，1988年12月までの 32 年間に慈恵医 大泌尿器科と, その関連病院で治療した腎細胞癌症例 482例の内, 腎摘が施行され, 直接腫崵径が測定可能で あった 431 例を検討対象とした。

これら対象症例を腫瘍の長径から, A 群 : $3.0 \mathrm{~cm}$ 以 下の群, B 群 : 3.1 5.9cm の群, C 群 : 6.0 9.9cm の群, $\mathrm{D}$ 群 : $10.0 \mathrm{~cm}$ 以上の症例群, に分類し以下の検 討項目について分析を試みた。

1）臨床的事項として，（a）罹患年齢，（b）性差，(c) 患側, (d) 徵候及び, 症状自覚から来院までの期間, （e）偶然発見例（尿路及び尿路外症状がいっさい認め られなくて, 他科疾患検索中に腎細胞癌が発見された 例）の占める頻度.

2) 病期 (stage) と組織学的悪性度 (grade) の分布.

3）各群別生存率からみた比較.

4）各群について,（a）病期（stage）別, (b) 悪性 度 (grade) 別比較検討.

の 4 項目について検討した.

なお, stage 分類は, Robsonの方式4k準じ, grade 分類は 4 段階分類 ${ }^{5}$ に従った。 比率の差に関する統計 的解析は, $Z$ 検定を用い, 生存率の差に関する検定は,
一般化 Wilcoxon 法で算出した.

$$
\text { 結果 }
$$

\section{1) 臨床的事項}

対象症例431例の内, A 群 $(3.0 \mathrm{~cm}$ 以下) は22例 (5.1\%), B 群 $(3.1 \sim 5.9 \mathrm{~cm})$ は121例 $(28.1 \%), \mathrm{C}$ 群 $(6.0 \sim 9.9 \mathrm{~cm})$ は209例 $(48.5 \%), \mathrm{D}$ 群 $(10.0 \mathrm{~cm}$ 以上 $)$

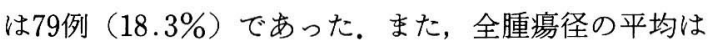
$7.5 \mathrm{~cm}$ （最小： $2.0 \mathrm{~cm}$, 最大 $: 18.0 \mathrm{~cm}$ ) であった。

(a) 罪患年齢：各群別に平均罹患年齢をみると, A 群 (59歳), B 群 (58.4歳), C 群 (57.4歳), D 群 (60.4 歳）と, 各群間に差はみられなかった。

(b) 性差：男子対女子の比に関して, 各群別にみる と, A 群 (2.14:1), B 群 (2.67:1), C 群 (2.48: 1), $\mathrm{D}$ 群 $(2.59: 1)$ と, 各群間に差はみられなかった。 (c) 患側：左右の比は, A 群 $(1.2: 1)$, B 群(1.1： 1), $\mathrm{C}$ 群 $(1.2: 1), \mathrm{D}$ 群 $(1: 1.02)$ と, 各群間で患側 の差は認められなかった。

（d）徵候及び, 症状自覚から来院までの期間：各群 別に比較した結果を示したのが，Fig. 1 である。るず, 腫瘍径が大きくなるにつれて，3 大尿路症状の占める

Fig. 1 症状からみた各群の比較

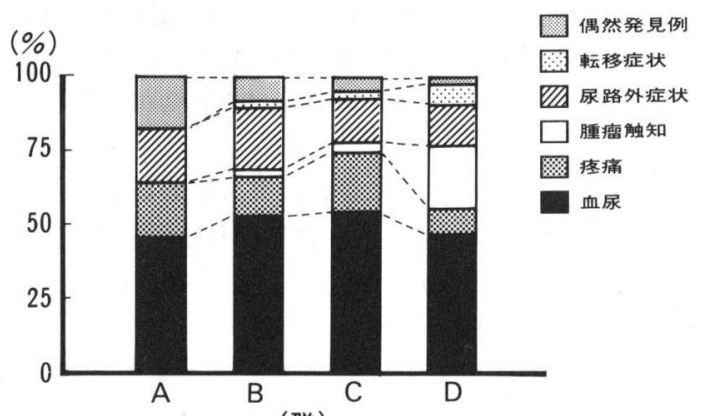

(群) 
割合が増加し，特に腫瘍径が $10 \mathrm{~cm}$ を越える群で腫瘤 を触知する傾向が強かった。 その他, 尿路外症状の占 める割合は各群間に差はなかった。

術前の発熱 $\left(37.0^{\circ} \mathrm{C}\right.$ 以上), 体重減少, 貧血, 赤沈の 六進 $(30 \mathrm{~mm} / \mathrm{hr}$ 以上) について各群の分布をみたもの が Fig. 2 である.

発熱については, 腫瘍径が $6 \mathrm{~cm}$ 以上の群 (C 群) が それ以下の群に比較して有意に増加していた $(\mathrm{p}<$ 0.05 ).

体重減少についても, 腫瘍径の増大に伴ってその頻 度が増加したが, 特に $6 \mathrm{~cm}$ 以上の群は, それ以下の群 に比較して頻度が高かった。

術前の貧血の有無についても，腫瘍径の増大に伴っ て, 貧血の占める頻度の増加が認められ, 特に $6 \mathrm{~cm}$ 越学る群で多く認められた。

赤沈の亢進についても, 腫瘍径が $6 \mathrm{~cm}$ を越觉る群 で，有意に立進例の占める割合の増加が観察された $(\mathrm{p}<0.01)$.

従って, 熱発, 体重減少, 貧血の有無, 赤沈の亢進 が多くみられるのは, 腫瘍径が $6.0 \mathrm{~cm}$ を越える群から であった，特に，赤沈の六進例にその傾向が強い結果 であった。

症状自覚から来院までの期間についてみたものが

Fig. 2

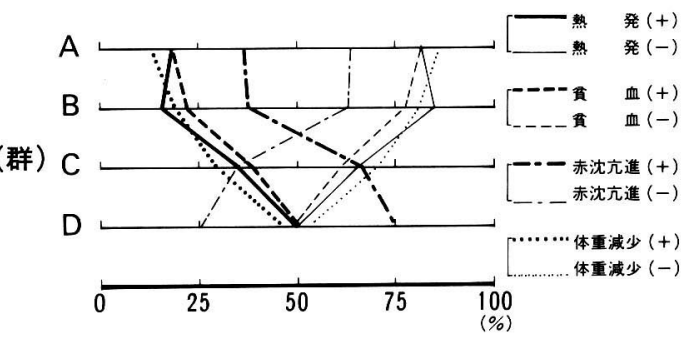

Fig. 3 症状自覚から来院までの期間

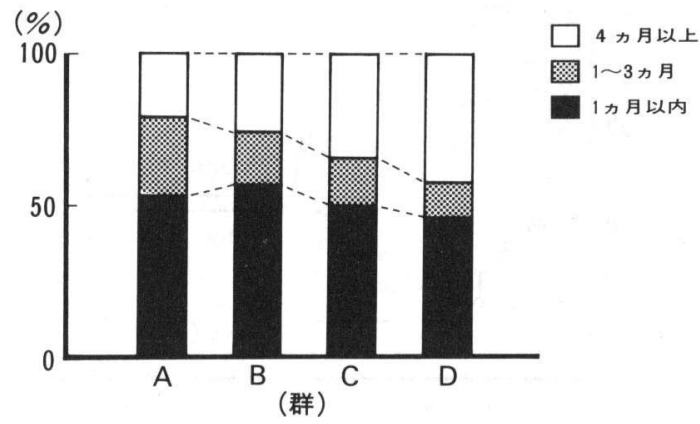

Fig. 3 である.その結果，1 1 月以内と，比較的早い 時期の来院例の占める割合が各群間に大きな差を認め ないこと， 1 から 3 カ月の中間の例が腫湯径が増大す るにつれて減少し，逆に，4 カ月以上の長い例が腫瘍 径の増大に伴って増加する結果であった。

（e）偶然発見例の占める頻度：偶然発見例の占める 頻度は, 各群別にみると, A 群がもっと多く(18.2\%), 他の群 (B 群；6.6\%，C 群；9.5\%，D群；2.5\%) に 比較して有意差が認められた $(\mathrm{p}<0.05)$ (Fig. 1). 李 た A 群の偶然発見例は，すべて超音波診断によるもの であった。杰た， B，C，D群間の偶然発見率に有意差 はなかった。

逆に，全偶然発見例（34例）中の各群別頻度をみる と, 最も多いのがC 群 (20例；58.9\%) で, 続いてB 群 ( 8 例 $; 23.5 \%), \mathrm{A}$ 群 ( 4 例；11.8\%), D 群 ( 2 例； $5.9 \%$ ) の順であった。

2) 病期（stage）と組織学的悪性度（grade）分布

a）各群別の stage 分布についてみると, 腫瘍径の増 大に伴って病期の進行した症例が増加する傾向にあ り，特に，転移を有する症例（stage 4）の占める割合 が, $3 \mathrm{~cm}$ を越光る症例で出現し，A 群に比較して B 群 (19例；15.7\%)，C群 (50例；23.9\%) 拈よびD 群 (30 例；38\%）間に有意差（p<0.05）がみられた。

b）各群別の grade 分布についてみると, stage 分布 同様，腫瘍径の増大に伴って grade の高い症例の占め る割合の増加が観察され，特に $3 \mathrm{~cm}$ 以下の症例と, $6 \mathrm{~cm}$ を越觉る症例間に high grade (grade III，IV) の症例 の占める割合 (A 群; $9.1 \%, \mathrm{~B}$ 群 ; 24.8\%, C 群 ; $46.4 \%, \mathrm{D}$ 群； $62.0 \%)$ に有意差 $(\mathrm{p}<0.01)$ が認めら れた。

Fig. 4 各群別生存率比較 (431症例)

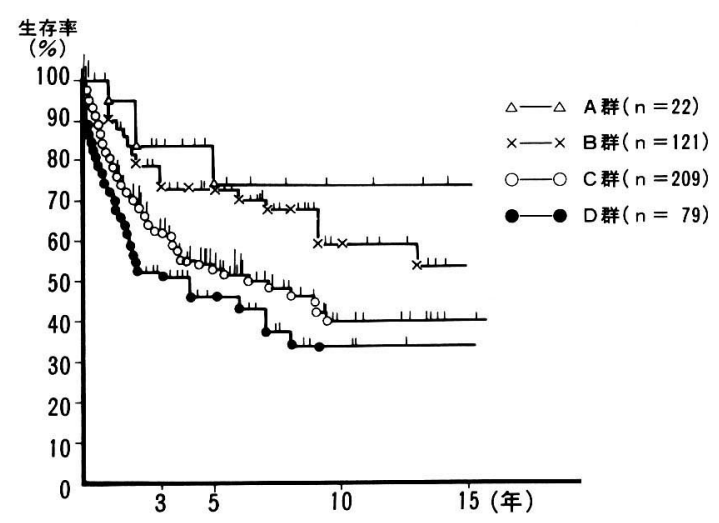


3）各群別生存率からみた比較

各群別に生存率を算出し, 比較したものが Fig. 4 で ある. A 群と B 群の比較では, 生存率に有意差は認め られなかった。しかし， $\mathrm{A}$ 群と $\mathrm{C}$ 群の比較では, 術 1 年以後 $\mathrm{A}$ 群が有意 $(\mathrm{p}<0.01)$ に生存率良好の結果であ り, $\mathrm{D}$ 群間についても同様の結果 $(\mathrm{p}<0.01)$ であった。 また, $\mathrm{B}$ 群と $\mathrm{C}$ 群間は術 3 年以後有意 $(\mathrm{p}<0.01)$ に $\mathrm{B}$ 群の生存率が良好であり，D群間 $(\mathrm{p}<0.01)$ について も同様の結果であった。しかし，C 群と D 群間には有 意差は認められなかった。

従って, 腫瘍径が $6 \mathrm{~cm}$ 以上と以下の群間では術 3 年 後から生存率に差がみられ，術後経過が長くなるほど 差は広がった。しかし, 腫瘍径が $6 \mathrm{~cm}$ を越光た群 (C 群, $\mathrm{D}$ 群) 間では, 腫痬径の増加に伴って生存率の低 下傾向がみられたが，有意差はなかった。

4）各群について,（a）病期（stage）別,（b）悪性 度 (grade) 別生存率比較検討

a) stage 別生存率

i ） A 群についてみると, stage 1が2に比較して生

Fig. 5 A 群の stage 別生存率比較

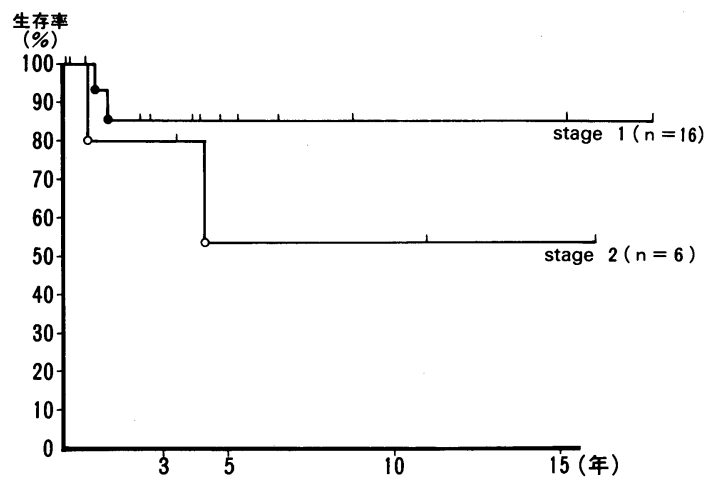

Fig. 6 B 群の stage 別生存率比較

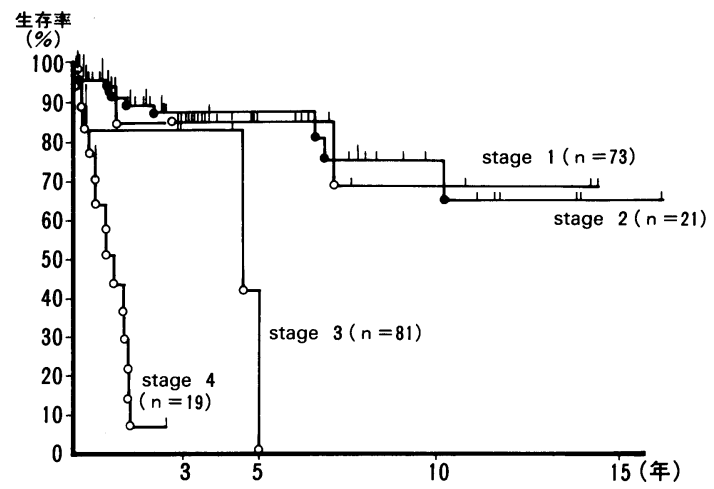

存率良好の傾向であったが，両群間に有意差は認めら れなかった (Fig. 5).

ii） B 群についてみると， stage 1，2間に差はなく， stage 1，4間（ $\mathrm{p}<0.1 ）$ 及び stage 2，4間（ $\mathrm{p}<0.05 ）$ に有意差が認められた（Fig. 6).

iii） C 群についてみると, stage 1, 2間に, 術 9 年以 後有意差 $(\mathrm{p}<0.05)$ があり, stage 1,3 間も, 術 1 年 以後有意差がみられ $(\mathrm{p}<0.01)$ ，さらに, stage 1,4 間にも術 1 年以後有意差 $(\mathrm{p}<0.001)$ が認められた。 また， stage $2 ， 3$ 間 $(\mathrm{p}<0.05)$ 及び， stage $3 ， 4$ 間 $(\mathrm{p}<$ 0.05 ににも術 $1 \sim 2$ 年の早期に有意差が認められた (Fig. 7).

iv） $\mathrm{D}$ 群についてみると, stage 2, 間以外の全ての stage 間に打いて生存率に有意差 (stage 1，2間； 1 年 以後, $\mathrm{p}<0.05$, stage 1,3 間； 1 年以後, $\mathrm{p}<0.5$, stage 1,4 間； 1 年以後, $\mathrm{p}<0.001$, stage 2,3 間 $; 1$ 年以 後, $\mathrm{p}<0.01$ ) が認められた.

以上まとめると, 腫瘍径が $3 \mathrm{~cm}$ 以下の群では, すべ て low stage（stage 1，2）で，生存率に差はみられな かった. 腫瘍径が3.1 5.9cm の群では, 遠隔転移をと もなった症例のみが有意に生存率が不良であった。腫 瘍径がさらに大きくなった $6.0 \sim 9.9 \mathrm{~cm}$ の群では，各 stage 間で生存率に有意差が認められ, 最も腫瘍径が 大い $10.0 \mathrm{~cm}$ を越える群では stage 1 と stage $2 ， 3$ ，さ らに stage 4 と,大きく 3 群間に生存率の差が認められ た.

b) grade 別生存率

i ) A 群についてみると, grade I, II と grade III

Fig. 7 C 群の stage 別生存率比較

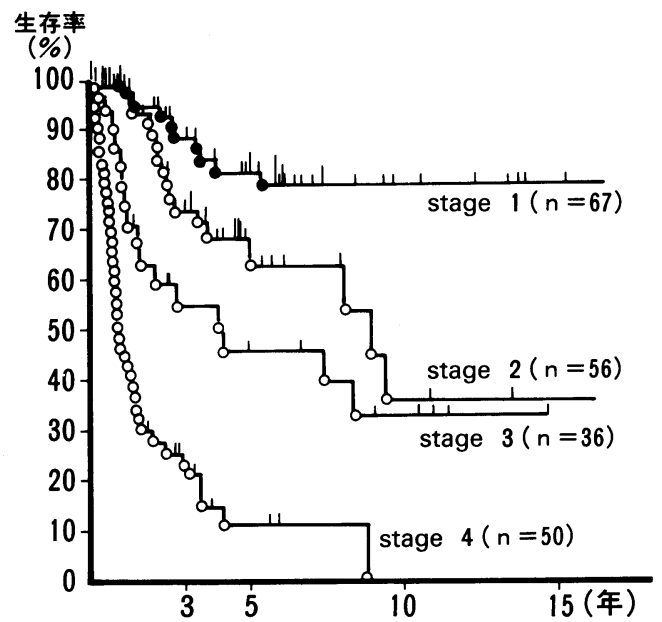


Fig. 8 A 群の grade 別生存率比較

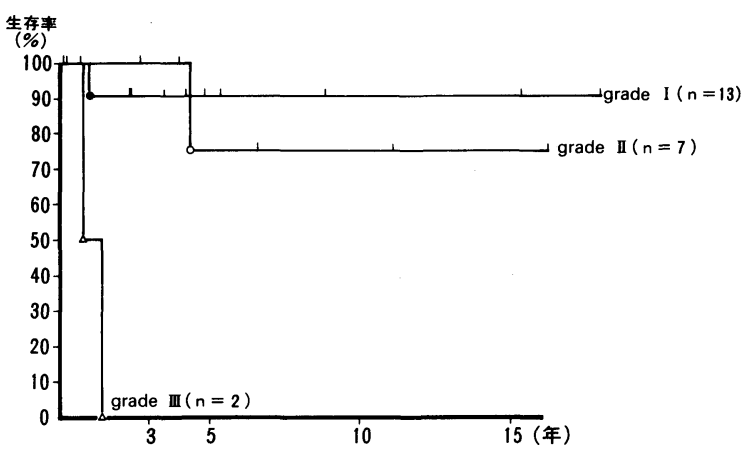

Fig. 9 B 群の grade 別生存率比較

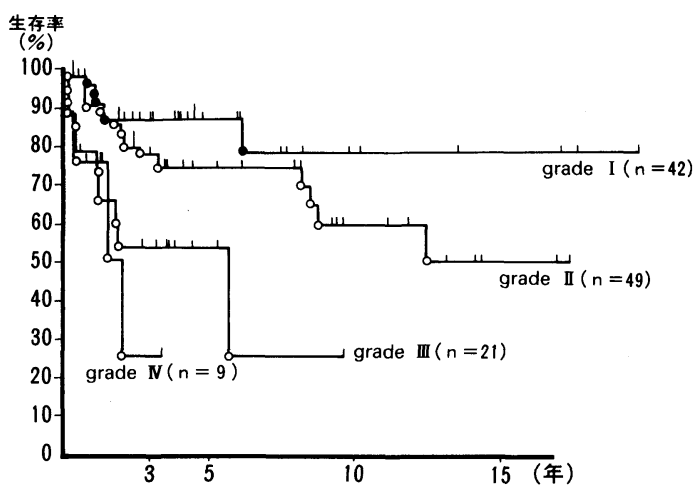

間に術 1 年以後有意差 $(\mathrm{p}<0.01)$ がみられた (Fig. 8).

ii） B 群についてみると, grade I, II 間, 及び grade III, IV 間以外全ての grade 間で有意差（grade I, III 間； 1 年以後, $\mathrm{p}<0.05$, grade I, IV 間； 2 年以後, $\mathrm{p}<0.01$, grade II, III 間； 2 年以後, $\mathrm{p}<0.05$, grade II, IV 間； 2 年以後, $\mathrm{p}<0.05)$ がみられた (Fig. 9). iii） C 群についてみると, 各 grade 間で生存率に有 意差がみられた(Fig. 10)。すなわち, grade I, II 間 ; 2 年以後, $\mathrm{p}<0.05$, grade I, III 間； 2 年以後, $\mathrm{p}<$ 0.001 , grade I, IV 間； 1 年以後, $\mathrm{p}<0.001$, grade II, III 間 ; 2 年以後, $\mathrm{p}<0.1$, grade II, IV 間 ; 1 年 以後, $\mathrm{p}<0.001)$ であった。

iv）D群についてみると, low grade (grade I, II) と high grade (grade III, IV) 間の生存率に有意差が 認められた。すなわち, grade I, III 間 ( 1 年以後, $\mathrm{p}<$ 0.01 ), grade I, IV 間 ( 1 年以後, $\mathrm{p}<0.05$ ), grade II, III 間 ( 1 年以後, $\mathrm{p}<0.05)$ 及び, grade II, IV 間 （ 1 年以後， $\mathrm{p}<0.05 ）$ において有意差が認められた. 以上まとめると, 腫禓径が $3.0 \mathrm{~cm}$ 以下の群でも,
Fig. 10 C 群の grade 別生存率比較

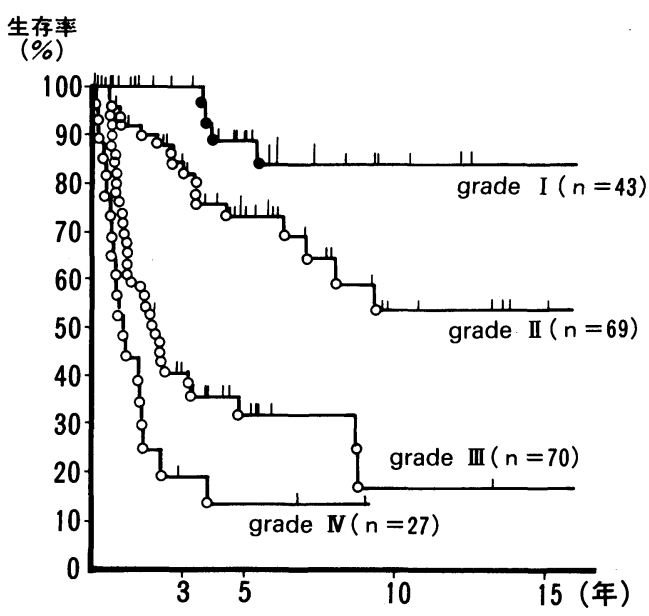

grade の高い例では生存率が悪く, 3.1 6.9cm の群で は, low grade と high grade 間で差がみられた。 また, 腫瘍径が6.0〜 9.9cm の群では, grade III, IV 間を除 く全ての grade 間で差が認められ, 最も大きい $10.0 \mathrm{~cm}$ を越える群でもC 群と同様の結果であった。

\section{考 察}

最近超音波画像診断法や, CTにより，腎細胞癌に関 連した徵候を伴うことなく，偶然に発見される症例が 多く報告されるよらになってきている1) 3). しかも，こ れら偶然発見例は，腫瘍径も小さい傾向があり，予後 も良好の傾向があるとい( ${ }^{1) ~ 3) . ~}$

腎細胞癌に対する有効な治療法は, 現在でも原発巣 の根治的切除である ${ }^{4)}$. しかし, 近年, 腫瘍径の小さい 症例を中心に，腎部分切除や核出術も行われはじめて おり，これら腎部分切除例は，根治的切除例に比較し ても予後に大きな差はないといら報告もある ${ }^{6) ~ 8)}$. 従って, 全ての症例に根治的切除を行らことに対する 疑問も生じはじめている.

この様な疑問を解決する目的で, 腎細胞癌の腫瘍径 の臨床的意義に注目して分析を試みた。

1）腫湯径の分布に関して

我々が用いた腫瘍径分類での頻度に関する他施設で の報告はないが, $3.0 \mathrm{~cm}$ 以下の腫湯の頻度は村松ら ${ }^{9)}$

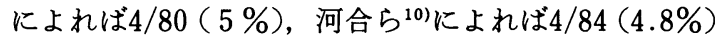
ときわめて少なく，出現率については我々の成績もほ ぼ同じであったまた，平均腫瘍径について比較する と, 村松 ら"9 $8.7 \mathrm{~cm}$, Medeiros ら ${ }^{11)} の 7.2 \mathrm{~cm}$, $\mathrm{Nurmi}^{12)}$ の $8.0 \mathrm{~cm}$ ，里見ら ${ }^{13)}$ の $7.0 \mathrm{~cm}$ などの報告とほ 
ぼ等しい結果であり，今回の検討症例が他の報告と比 較して大きな偏りはないと考えられる。

2）腫瘍径からみた臨床症状

3 大症状からみると血尿や疼痛に関しては, 腫瘍の 大きさと関係がない結果であった。すなわち, 腫瘍径 が $3.0 \mathrm{~cm}$ 以下の症例でも, 顕微鏡的血尿の有無は, 腎 細胞癌発見にとって, $3.0 \mathrm{~cm}$ を越える群同様重要な徵 候であることを示唆している。

尿路外症状の内で, 発熱, 体重减少は, 腎細胞癌の 予後を検討する上で重要な徵候とされている(14)15)。こ れら徴候の出現頻度を腫場径からみると, A, B 群間に 差はみられず,これら両群と, C 群間に差が認められる 結果であった。 さらに, 貧血の有無, 赤沈の克進に関 しても，尿路外症状と同様の結果であることを考光合 わせると, 腫瘍径が $6.0 \mathrm{~cm}$ を越えるあたりから, 腎細 胞癌の有する腫瘍側因子の宿主に対する影響が顕著と なることを示唆しており，きわめて興味ある現象であ る.

\section{3）偶然発見例と腫瘍径に関して}

我々の症例は, 偶然発見例の占める頻度（34例；

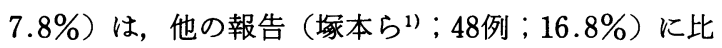
較して低い結果であった。この原因は，まず，偶然と いう言葉の定義が各報告者で異なるため, 比較症例数 に差を生じていると考学られる。 また，我々の検討症 例が，かなり古い時代からの集積結果であるため, 腎 細胞癌の診断にいたるアプローチが以前と異なること も一因と考支られる。その第一が, 超音波画像診断法 の普及であり，第二がCT の出現である.

特に最近, 超音波画像診断法を用いた検索によって 腎細胞癌が発見される頻度が高まっており，そのため 理学的診察の一環に超音波画像診断を入れるべきとす る意見もある(10).

しかし, 才田ら ${ }^{16)}$ の10,914例にのぼる超音波画像診 断法による mass screening の結果, 15 例 $(0.14 \%)$ に 腎細胞癌が発見されたとしている。これら症例の腫瘍 径は3.5 10cm と必ずしも小さい例ばかりではない。 さらに，塚本らの報告1)によれば, 全偶然発見例の腫瘍 径は平均 $6.2 \mathrm{~cm}$ であり, 腫瑒径からみれば, $6.0 \mathrm{~cm}$ 代 がもっと多く, 続いて $4.0 \mathrm{~cm}$ 代と報告している．従っ て, 必ずしも小さい例のみが偶然に発見されるとは限 らず，我々も同様の傾向であった。

4）腫瘍径, stage, grade と予後の関係について

今回の検討から, 腫瘍径の増大にともなって, stage や, grade も高くなる傾向が認められた. しかし,一般
に腫瘍の長経と予後との関連に関してはまだ結論が出 ていな(11112)14)17). 里見 ${ }^{18)}$, Bell $5^{191}$ は3.0cm 以下の腫 瘍を早期癌あるいは，良性の傾向を有する癌と述べて いる。しかし我々の検討では, 腫瘍径が, $3.0 \mathrm{~cm}$ 以下 の群と, $3.1 \sim 5.9 \mathrm{~cm}$ の群間に生存率に有意差が認め られなかった。このことは, $3.0 \mathrm{~cm}$ 以下の腫瘍でも, 予想される以上に生存率が良くないことを示唆してお り, $3.0 \mathrm{~cm}$ 以下の腫瘍が決して楽観できない腫瘍であ ると考兄らる。

各腫瘍径群について, stage が生存率に及ぼす影響 についてみると, 手術時遠隔転移を有する症例を除く と, 腫瘍径が $5.9 \mathrm{~cm}$ までの例では, stage 1, 2間に差 は認められない結果であった。逆に, grade について検 討すると, 腫揚径が, $3.0 \mathrm{~cm}$ 以下の症例群でも, さら に3.1 5.9cm までの症例群についても, grade II と III 間に生存率に有意差が認められた。つまり, 比較的 腫瘍径が小さい症例については, stage より, grade が 生存率に関してょり重要であることを示唆したものと 考えられる。

Tomera ら ${ }^{20)}$ は, grade I で腫瘍径が $2 \sim 3 \mathrm{~cm}$ の症例 の 5 年生存率を $73.9 \%$ と報告しており, 腫瘍径が小さ く, かつ grade が低い症例についても決して予後が良 くないと報告している。また, Medeirosら ${ }^{11)}$ は, 腫場 径が $5 \mathrm{~cm}$ 以下の症例で, grade I, II の症例の 5 年生存 率を約 $90 \%$ と報告して抒り, grade の低い症例は予後 良好であると報告している。

Tomera ら ${ }^{20)}$ の報告では, 腫瘍径が $3 \mathrm{~cm}$ を越える症 例について, 腫瘍径は予後と関連が少ないとしている。 逆に, Medeiros ら ${ }^{11}$, Nurmi ら ${ }^{12}$ によれば, 腫瘍径が $5 \mathrm{~cm}$ 以下の群と, $10 \mathrm{~cm}$ 以上の群では生存率に有意差 があるとしている.

我々の検討から, 腫瘍径が $3.0 \mathrm{~cm}$ 以下の症例でも, $9 \%$ 程度は grade の高い例があり，これら症例につい ては, 手術のみで根治的と考劣るのは危険で, 経過観 察も含めて十分注意する必要があることを強調した い. 病理組織学的検討から腫瘍径が小さい $(3.0 \mathrm{~cm}$ 以 下）症例の予後を検討した鈴木の報告 ${ }^{211}$ からもこの結 果は明かである.

5）腎部分切除（あるいは核出術）について

腎細胞癌に対する, 部分切除あるいは, 腫瘍核出術 は, 従来より両側, あるいは単腎に発生した腫場, あ るいは対側の腎機能低下症例に適応があるとされてい た。しかし最近小さい病変を有する症例を中心に, 積 極的に罹患側の腎機能も保存する手術が行われ始めて 
いる。

Novick ら ${ }^{22)}$ は, 両側発生 20 例, 単腎発生13例を対象 とした核出術施行33症例を術後経過観察した報告を 行っている。それによれば， 3 年生存率 $90 \%$ ，局所再 発をわずか 2 例（6\%）に認めたのみで，良好な成績 を発表している。しかしこの報告を，腫瘍径からみる と, $2 \mathrm{~cm}$ から $8 \mathrm{~cm}$ と, 決して小さい症例のみを対象と していない.

Marshall ら ${ }^{23)}$ は，9例に ex vovo で腫瘍核出術を行 い，核出腫瘍床に癌細胞を認めなかったにもかかわら ず，静脈浸潤 1 例， 1 年半後に対側腎転移 1 例，さら に被膜外浸潤症例を 1 例に認めたと報告し, 核出術よ り，切除範囲のやや広い部分切除の方を推薦している。 しかし, Marshall ら ${ }^{23)}$ の検討症例は, 腫瘍径が $5 \mathrm{~cm}$ か $ら 12 \mathrm{~cm}$ と, Novick ら ${ }^{22)}$ の症例に比較して腫瘍径が大 きく, しかも, 静脈浸潤, 転移, 被膜外浸潤例は, 腫 瘍径がそれぞれ， $8.5,12,5 \mathrm{~cm}$ と，大きな腫瘍であっ たと報告して括り，これら報告からも，腎部分切除や 核出術の適応は, grade に加えて, 腫瘍径の小ささも重 要な要素であることは事実と考えられる。

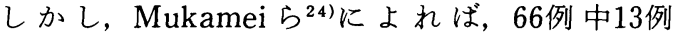
（19.7\%）に，一見肉眼的に正常と思われた腎被膜下， あるいは腎皮質内に腎細胞癌の小病変が多数播種して いる結果を報告しており，腎部分切除の適応の再検討 を勧めている．今後さらに，腫瘍径が $3 \mathrm{~cm}$ 以下と小さ く, 乙かも grade が低い症例が，腫瘍核出術や，部分 切除の適応となるか, Mukamei ら ${ }^{24)}$ の報告も含めて 詳細に検討する必要があると考えられる。

\section{結 語}

過去 32 年間に慈恵医大泌尿器科及びその関連病院で 治療した腎細胞癌の内, 腎摘除術が施行された 431 症例 について，腫瘍の長経から 4 群（A 群； $3.0 \mathrm{~cm}$ 以下； 22例，B 群；3.1 5.9cm；121例，C 群；6.0 9.9 $\mathrm{cm} ; 209$ 例, $\mathrm{D}$ 群 ; $10 \mathrm{~cm}$ 以上; 79例)に分類し, 各群 別に臨床的特徵や，予後との関連について比較検討し た.

1）罹患年齢，性差，患側は，各群間に差は認められ なかった。

2）症状からみると，腫瘍径の増大に伴って，尿路症 状の頻度が高く, 特に腫瘍径が $10 \mathrm{~cm}$ 以上の群で腫瘤 を触知する傾向が強かった。 また，血尿の頻度及び， 尿路外症状の頻度は各群間に差はなかった。

3）熱発，体重減少，貧血，赤沈の充進の頻度は，腫 瘍径が $6.0 \mathrm{~cm}$ を越える群から多く認められる傾向に
あった。

4） stage, grade の分布は, 腫瘍の増大に伴って高く なり, 特に, stage $4 \mathrm{~B}$ の症例にこの傾向が強く認めら れた。

5）各群別生存率では，A，B 群間と C，D群間を除 く他の群間の生存率に有意差が認められた。

6）各群について, stage 及び grade 別に生存率を分 析すると, 特に A 群について stage より grade が生存 率を左右する結果であった。

本論分の要旨は, 第54回日本泌尿器科学会東部総会に打 いて発表した。

\section{文献}

1）塚本泰司，熊本悦明，山崎清代，宮尾則臣，高橋 敦：偶然発見される腎細胞癌の臨床的検討．腎と 透析, 26, 411-415, 1989.

2）河邊香月：偶然発見された腎細胞癌（発見の契機 の考察と発見法としての超音波診断法). 臨泌, 42, 1045-1054, 1988.

3) Konnak, J.W. and Grossman, H.B. : Renal cell carcinoma as an incidental finding. J. Urol., 134, 1094-1096, 1985.

4) Robson, C.J., Churchill, B.M. and Anderson, W. : The results of radical nephrectomy for renal cell carcinoma. J. Urol., 101, 297-301, 1969.

5) Bannayan, G.A. and Lamm, D.L.: Renal cell tumors. Pathol. Ann., 15, 271-308, 1980.

6) Topley, M., Novick, A.C. and Montie, J.E.: Long-term results following partial nephrectomy for localized renal adenocarcinoma. J. Urol., 131, 1050-1052, 1984.

7) Marberger, M., Pugh, R.C.B., Auvert, J., Bertermann, H., Constatini, A., Gammelgaard, P.A., Petterson, S. and Wickam, J.E.A.: Conservative surgery of renal carcinoma: The EIRSS experience. Brit. J. Urol., 53, 528-532, 1981.

8）高寺博史, 宇都宮正登, 伊東 博, 坂板宏彬, 吉岡 俊昭, 並木幹夫：腎腫瘍に対する腫煬核出術の検 討。日泌尿会誌，79，1544-1549，1988。

9）村松幸男, 森山紀之, 高安賢一, 垣添忠生: 後腹膜 臓器の微小癌. A. 各種画像䛦断法による $5 \mathrm{~cm}$ 以下 の腎癌の検出能の比較検討. 病理之臨床, 5, 249-259, 1987.

10）河合恒雄, 山内民男, 立花裕一, 吉野修司, 國保昌 紀：腎・膀胱・前立腺・睪丸．癌の臨床，34， 1403-1407, 1988

11) Medeiros, L.J., Gelb, A.B. and Weiss, L.M.: Renal cell carcinoma. Prognostic significance of morphologic parameters in 121 cases. Cancer, 61, 1639-1651, 1988.

12) Nurmi, M.J.: Prognostic factors in renal car- 
cinoma. An evaluation of operative findings. Brit. J. Urol., 56, 270-275, 1984.

13）里見佳昭, 福田百邦, 穂坂正彦, 近藤猪一郎, 吉邑 貞夫, 福島修司, 井田時雄, 広川 信, 森田 上, 古畑哲彦, 熊谷治巳, 塩崎 洋, 石塚栄一, 宮井啓 国, 仙賀 裕, 福岡 洋, 佐々木紘一, 公平昭男, 中橋 满：腎癌の予後に関する臨床的検討. 日泌 尿会誌, 79, 853-863， 1988.

14）真田壽彦：腎細胞癌の予後. 日泌尿会誌, 72, 10-25, 1981.

15）宮原 茂, 住吉 修, 村上雅巳, 植田省吾, 松岡 啓, 野田信士, 江藤耕信 : 腎細胞癌の臨床的研究 一予後規制因子一. 西日泌尿会誌，50，45-51， 1988.

16）才田博彦, 大山朝弘, 松川正男, 福嶋 浩, 沖栄真 恵：腎超音波検査 10,914 例の検討. 第 II 報：腎癌 の早期発見について。西日泌尿会誌, 49, 1035 $-1037,1987$.

17) Golimbu, M., Tessler, A., Joshi, P., Al-Askari, S., Sperber, A. and Morales, P.: Renal cell carcinoma: Survival and prognostic factors. Urology, 27, 291-301, 1986.

18）里見佳昭, 仙賀 裕, 福田百邦, 中橋 満, 穂坂正 彦, 近藤猪一郎, 吉邑貞夫, 福島修司, 古畑哲彦,
塩崎 洋, 石塚栄一, 福岡 洋: 腎癌333例の臨床 統計的観察. 第 3 報. 手術, 手術所見及び手術成績. 日泌尿会誌, 78, 1394-1402，1987.

19) Bell, E.T.: A classification of ranal tumors with observations on the frequency of the various type. J. Urol., 39, 238-243, 1938.

20) Tomera, K.M., Farrow, G.M. and Lieber, M.M. : Well differentiated (grade I) clear cell carcinoma. J. Urol., 129, 933-937, 1983.

21) 鈴木正章 : 小さい腎癌 (長径 $3 \mathrm{~cm}$ 以下)の臨床病理 学的検討. 慈恵医誌, $100,815-832,1985$.

22) Novik, A.C., Zincke, H., Neves, R.J. and Topley, H.M. : Surgival enucleation for renal cell carcinoma. J. Urol., 135, 235-238, 1986.

23) Marshall, F.F., Taxy, J.B., Fishman, E.K. and Chang, R. : The feasibility of surgical enucleation for renal cell carcinoma. J. Urol., 135, 231-234, 1986.

24) Mukamei, E., Konichezky, M., Engelstein, D. and Servadio, C.: Incidental small renal tumors accompanying clinically overt renal cell carcinoma. J. Urol., 14, 22-24, 1988.

（1989年11月15日受理） 